ISSN 1112-9867

\title{
SYNTHESIZED AND EXTENDING THE BIDENTATE SCHIFF BASE COMPLEXES USING MULTILAYER FEEDFORWARD NEURAL NETWORK
}

\author{
A. M. Tajuddin ${ }^{1,3}$, N. Ismail ${ }^{2, *}$, K. Kassim ${ }^{4}$ and H. Bahron ${ }^{3}$ \\ ${ }^{1}$ Atta-ur-Rahman Institute, UniversitiTeknologi MARA, 42300 PuncakAlam, Selangor, \\ Malaysia \\ ${ }^{2}$ Faculty of Electrical Engineering, UniversitiTeknologi MARA, 40450 Shah Alam, Selangor, \\ Malaysia \\ ${ }^{3}$ Faculty of Applied Sciences, UniversitiTeknologi MARA, 40450 Shah Alam, Selangor, \\ Malaysia \\ ${ }^{4}$ Institute of Science, UniversitiTeknologi MARA, 40450 Shah Alam, Selangor, Malaysia
}

Published online: 05 October 2017

\begin{abstract}
Complexes of $\mathrm{Pd}(\mathrm{II})$ and $\mathrm{Ni}$ (II) have been synthesized with general composition $\mathrm{ML}_{2} \mathrm{X}_{2}(\mathrm{M}=$ $\mathrm{Pd}(\mathrm{II}), \mathrm{Ni}(\mathrm{II}) ; \mathrm{L}=$ benzylsalicylideneimine and $\left.\mathrm{X}=\mathrm{OCH}_{3}, \mathrm{~F}\right)$. All synthesized compounds have been characterized using elemental analysis, magnetic susceptibility measurements, infrared and NMR spectral studies that led to the conclusion that the ligands act as bidentate manner to form square planar geometry for all complexes. As an extending work, the model development of these complexes using multilayer feedforward neural network were performed. NiL1d, PdL1d, NiL1c and PdL1c were fed to the training network as inputs and bacteria as output. Levenberg Marquardt training algorithm was used during the network training with 10 nodes in hidden layer. The results of testing network showed that the regression, $\mathrm{R}$ is 1 , indicating that the developed model is good.
\end{abstract}

Author Correspondence, e-mail: nurlaila@ieee.org

doi: http://dx.doi.org/10.4314/jfas.v9i4s.57 
This is supported by the small mean square error (MSE) is $1.948 \times 10^{-28}$ at epochs 5 . The finding in this study is significant, thus contributed to the design of antibacterial agent especially to the bidentate Schiff base complexes.

Keywords: Schiff base, palladium(II), nickel(II), antibacterial, regression, neural network.

\section{INTRODUCTION}

\subsection{Schiff Base Ligands}

Schiff bases derived by the condensation of primary amines with carbonyl compounds and they contain azomethine group $(-\mathrm{CH}=\mathrm{N}-)$ [1] that represent an important chelating ligands which have been studied extensively. Schiff bases are usually bi-, tri- and tetra-dentate ligands which capable of forming stable transition metal complexes [1-2].

The chemistry of the metal complexes of the Schiff bases containing nitrogen and other donor atoms has attracted a great deal of attention due to their stability, biological activity [3] and potential applications in many fields such as catalysis and electrochemistry [4]. Thus, synthesis of Schiff bases and their metal complexes has been the main objective of many current studies.

\subsection{Multilayer Feedforward Neural Network}

Among many current studies, the investigation on antibacterial activity especially on Schiff bases by neural network is still new [5]. Neural network or multilayer feed forward neural network is a data processing technique or algorithm that acting as human brain to activate the signal for processing. In order to achieve some applications on pattern recognition, classification, prediction and controlling, the network functioning based on biological neural system. This highly parallel interconnected system is built by neurons or nodes which are connected together. The expression for the output of an $\mathrm{i}^{\text {th }}$ hidden neuron in the $1^{\text {th }}$ layer, $x(t)$ is given by [6]:

$x_{i}^{l}(t)=f\left(v_{i}^{l}(t)\right), l=1,2, \ldots, m, \quad i=1,2, \ldots, n_{l}$

where $n_{l}$ is the layer's size of $l$ and $f($.$) is the activation function or non linear$ transformation. The sigmoid function is updated to become as,

$x_{i}^{l}(t)=\sum_{i=1}^{n_{l}-1} w_{i j}^{l} x_{j}^{l-1}(t)+b_{i}^{l}$ 
where $b$ is the bias or the network threshold. The bias is considered as unit 0 and it is equal to 1.The weight, $w_{i j}^{l}$ is the weight connection between the $j$ th neuron of the $(l-1)$ th layer and theith neuron of the $(l-1)$ th layer. The weights are used to adjust the strength of the signal propagating through it. The output of each neuron is defined as:

$x_{i}^{l}(t)=f\left(\sum_{i=1}^{n_{l}-1} w_{i j}^{l} x_{j}^{l-1}(t)+b_{i}^{l}\right)$

it also can be expressed as:

$\widehat{y_{s}}=F\left(v(t)_{n}\right) s=0, i, \ldots, n_{m}$

The structure of multilayer feed forward network with one hidden layer is demonstrated in Fig.

1.

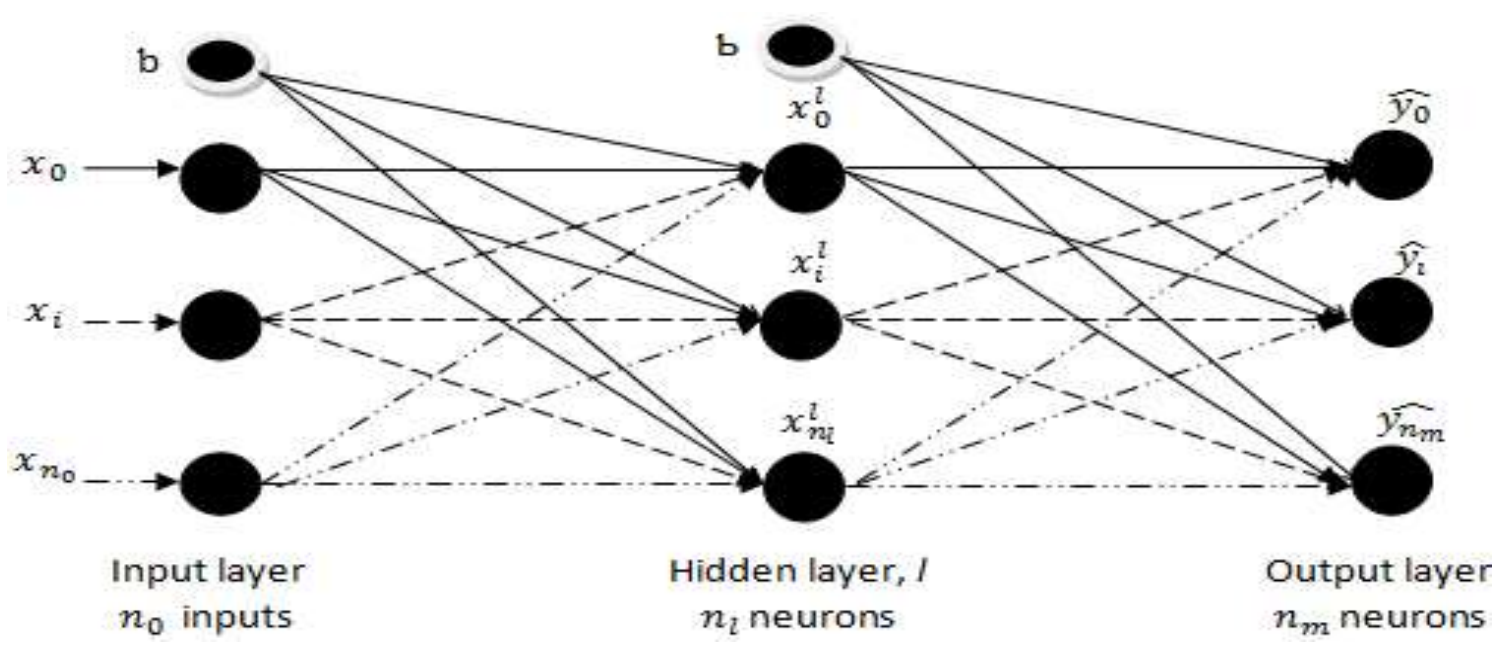

Fig.1. A multilayer feed forward neural network [6]

In this study, we have synthesized bidentate Schiff base ligands using $o$-vanillin as a starting material and their Pd(II) and Ni(II) metal complexes. All of the synthesized compounds were characterized using several analytical and spectroscopic techniques. All synthesized compounds have been screened for their antibacterial activity against gram-positive and gram-negative bacteria. After that, the extending work is performed to model the complexes against bacteria by applying Levenberg Marquardt training algorithm. Then, it is followed by network performance measurement by using regression and mean square error (MSE).

\section{METHODOLOGY}

All reagents and solvents used were laboratory pure grade available from Acros Organics (USA), Merck (Germany) and Sigma-Aldrich (USA). The antibacterial testing were provided 
by School of Biosciences and Biotechnology Study, Faculty of Science and Technology, UniversitiKebangsaan Malaysia. Compounds that tested for antibacterial were PdL1c, NiL1c, PdL1d and NiL1d based on their criteria as single crystals. Three pathogenic bacterial strains (Bacillus subtilis(ATCC10536) and Staphylococcus aureus(ATCC 11774) (Gram-positive) and Escherichia coli (ATCC 11632) (Gram-negative)) were used to screen the antibacterial potential of the complexes.

\subsection{Synthesis of Schiff Base Ligands}

Schiff base ligands were reacted between salicylaldehyde and benzylamine derivatives $(1: 1$ molar ratio) in ethanol. The solution was refluxed for an hour to give yellow semicrystalline solid upon cooling. The solid was filtered off, washed with ice-cold EtOH and air-dried at room temperature (Fig. 2).
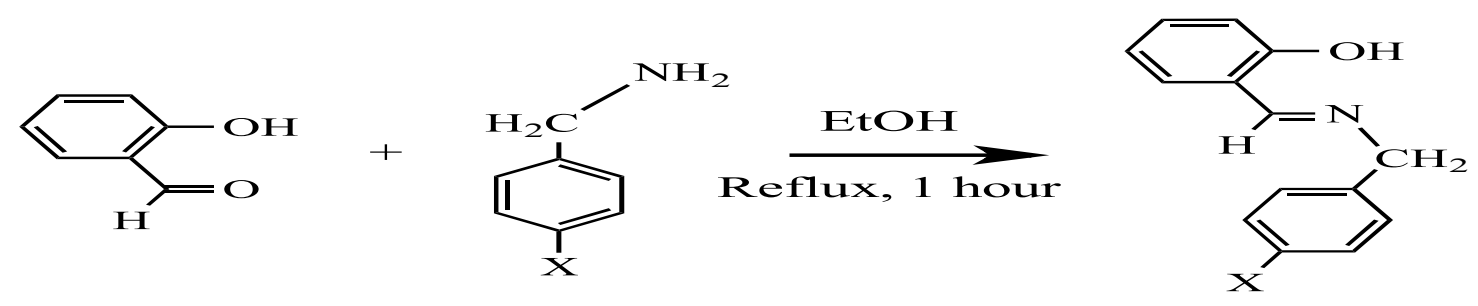

$$
\mathrm{X}: \mathrm{H}, \mathrm{CH}_{3}, \mathrm{OCH}_{3}, \mathrm{~F}
$$

Fig.2. General synthesis of ligands

\subsubsection{Synthesis of N-4-Methoxybenzylsalicylideneimine [L1c]}

Yellow solid; yield, 68.2\%. ${ }^{1} \mathrm{H}$ NMR $\left(300 \mathrm{MHz}, \mathrm{CDCl}_{3}\right): \delta 4.74\left(\mathrm{~s}, 2 \mathrm{H}, \mathrm{CH}_{2}\right), 3.80(\mathrm{~s}, 3 \mathrm{H}$, $\left.\mathrm{Ar}-\mathrm{OCH}_{3}\right), 6.84-7.30$ (phenylic hydrogen groups), $8.40(\mathrm{~s}, 1 \mathrm{H},=\mathrm{CH}), 13.48(\mathrm{~b}, 1 \mathrm{H}, \mathrm{OH}) .{ }^{13} \mathrm{C}$ NMR $\left(300 \mathrm{MHz}, \mathrm{CDCl}_{3}\right): \delta 55.3\left(\mathrm{Ar}-\mathrm{OCH}_{3}\right), 62.5\left(\mathrm{CH}_{2}\right), 114.0,117.0,118.6,131.4,132.2$ (ArC), $165.1(\mathrm{C} 1-\mathrm{OH}), 161.1(\mathrm{~N}=\mathrm{CH})$. Anal. Calcd for $\mathrm{C}_{15} \mathrm{H}_{15} \mathrm{NO}_{2}$ : C, 74.67; H, 6.27; N, 5.80\%; Found: C, 74.77; H, 6.28; N, 5.97\%. IR $\left(\mathrm{KBr}, \mathrm{cm}^{-1}\right): 1630 v(\mathrm{C}=\mathrm{N}), 1326 v(\mathrm{C}-\mathrm{N})$, $1248 v(\mathrm{C}-\mathrm{O})$.

\subsubsection{Synthesis of N-4-Fluorobenzylsalicylideneimine [L1d]}

Yellow liquid. Anal. Calcd for $\mathrm{C}_{14} \mathrm{H}_{12}$ FNO: C, 73.35; H, 5.28; N, 6.11\%; Found: C, 71.06; H, 5.28; N, 5.84\%. IR (KBr, $\left.\mathrm{cm}^{-1}\right): 1630 v(\mathrm{C}=\mathrm{N}), 1350$ v(C-N), $1220 v(\mathrm{C}-\mathrm{O})$.

\subsection{Synthesis of Metal Complexes}

Metal acetate was dissolved in acetonitrile $(\mathrm{MeCN})$ and added dropwise to the ligand solution 
in 1:2 molar ratio. The mixture was stirred and heated under refluxed for 5 hours upon which coloured solid was formed. The solid was filtered off, washed with ice-cold MeCN and air dried at room temperature. The solid product was recrystallized from chloroform yielding yellow/orange crystals (Fig. 3).


M: Pd(II), Ni(II); X: $\mathrm{OCH}_{3}, \mathrm{~F}$

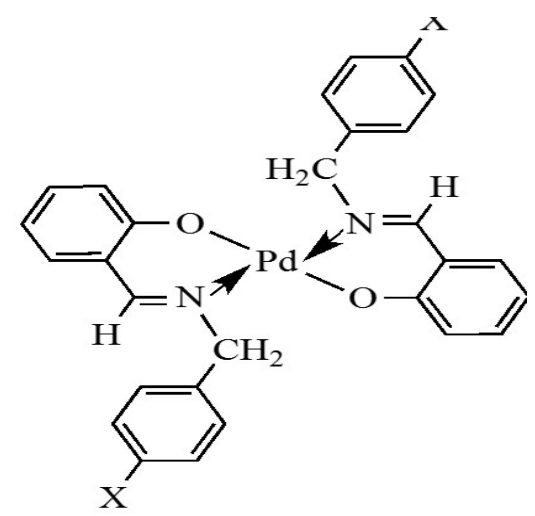

Fig.3. General synthesis of metal complexes

\subsubsection{Synthesis of Bis(2-((E)-(4-methoxybenzylimino)phenolato)palladium(II) [PdL1c]}

Yellow solid; yield, 91.2\%; m.p. 230-238 ${ }^{\circ} \mathrm{C} .{ }^{1} \mathrm{H}$ NMR (300 MHz, $\mathrm{CDCl}_{3}$ ): $\delta 4.93$ (s, 2H, $\mathrm{CH}_{2}$ ), $3.78\left(\mathrm{~s}, 3 \mathrm{H}, \mathrm{Ar}-\mathrm{OCH}_{3}\right), 6.52-7.37$ (phenylic hydrogen groups), $7.69(\mathrm{~s}, 1 \mathrm{H},=\mathrm{CH}) .{ }^{13} \mathrm{C} \mathrm{NMR}$ (300MHz, $\left.\mathrm{CDCl}_{3}\right): \delta 55.2\left(\mathrm{Ar}-\mathrm{OCH}_{3}\right), 58.5\left(\mathrm{CH}_{2}\right), 114.0,120.3,129.6,134.2,134.7(\mathrm{ArC})$, $162.8(\mathrm{~N}=\mathrm{CH})$. Anal. Calcd for $\mathrm{C}_{30} \mathrm{H}_{28} \mathrm{~N}_{2} \mathrm{O}_{4} \mathrm{Pd}$ : C, 61.39; H, 4.81; N, 4.77\%; Found: C, 61.63; H, 3.67; N, 4.71\%. IR (KBr, cm $\left.{ }^{-1}\right): 1606$ v(C=N), 1342 v(C-N), 1318 v(C-O), 596 v(Pd-N), $434 \mathrm{v}(\mathrm{Pd}-\mathrm{O})$.

\subsubsection{Synthesis of Bis(2-(4-fluorobenzyliminomethyl)phenolato)palladium(II) [PdL1d]}

Orange solid; yield, 33.9\%; m.p. 253-257 ${ }^{\circ} \mathrm{C}$. Anal. Calcd for $\mathrm{C}_{28} \mathrm{H}_{22} \mathrm{~F}_{2} \mathrm{~N}_{2} \mathrm{O}_{2} \mathrm{Pd}$ : C, 59.74; $\mathrm{H}$, 3.94; N, 4.98\%; Found: C, 58.28; H, 3.94; N, 3.69\%. IR (KBr, $\left.\mathrm{cm}^{-1}\right): 1618 v(\mathrm{C}=\mathrm{N}), 1341$ $v(\mathrm{C}-\mathrm{N}), 1221 v(\mathrm{C}-\mathrm{O}), 596 \mathrm{v}(\mathrm{Pd}-\mathrm{N}), 494 \mathrm{v}(\mathrm{Pd}-\mathrm{O})$.

\subsubsection{Synthesis of $\operatorname{Bis(2-((E)-(4-methoxybenzylimino)methyl)phenolato)nickel(II)~}$ [NiL1c]}

Green solid; yield, 43.3\%; m.p. 196-199 ${ }^{\circ} \mathrm{C}$. Anal. Calcd for $\mathrm{C}_{30} \mathrm{H}_{28} \mathrm{~N}_{2} \mathrm{O}_{4} \mathrm{Ni}$ : C, 66.82; H, 5.23; N, 5.19\%; Found: C, 67.03; H, 5.28; N, 5.15\%. IR $\left(\mathrm{KBr}, \mathrm{cm}^{-1}\right): 1605 v(\mathrm{C}=\mathrm{N}), 1391$ $v(\mathrm{C}-\mathrm{N}), 1325 v(\mathrm{C}-\mathrm{O}), 598 v(\mathrm{Ni}-\mathrm{N}), 437 v(\mathrm{Ni}-\mathrm{O})$. 


\subsubsection{Synthesis of Bis(2-((E)-(4-fluorobenzylimino)methyl)phenolato)nickel(II) [NiL1d]}

Green solid; yield, 68.6\%; m.p. $198-203{ }^{\circ} \mathrm{C}$. Anal. Calcd for $\mathrm{C}_{28} \mathrm{H}_{22} \mathrm{~F}_{2} \mathrm{~N}_{2} \mathrm{O}_{2} \mathrm{Ni}$ : C, 65.28; $\mathrm{H}$, 4.30; N, 5.44\%; Found: C, 65.87; H, 4.39; N, 5.55\%. IR $\left(\mathrm{KBr}, \mathrm{cm}^{-1}\right): 1612 v(\mathrm{C}=\mathrm{N}), 1390$ v(C-N), $1221 v(\mathrm{C}-\mathrm{O}), 597 \mathrm{v}(\mathrm{Ni}-\mathrm{N}), 451 \mathrm{v}(\mathrm{Ni}-\mathrm{O})$.

\subsection{Multilayer Feedforward Neural Network}

The complexes are analyzed using the MATLAB software version R2014a [7]. The diameter of four compounds (NiL1d, PdL1d, NiL1c and PdL1c) are fed into neural network as input and bacteria (E. coli, B. subtilisand S. aureus) as output. For training multilayer feedforwards, Levenberg Marquardt algorithm is used to optimize the performance function as well as updates the network weight and biases. The network is trained using MATLAB script function of feedforwardnet. This training supervised algorithm is well known as the fastest backpropagation algorithm in the MATLAB version R2014. Not limited to that, it does require more memory than other algorithms.

After that, the feedforward training network is tested by the performance function Mean Square Error (MSE) and regression plot. Mean Square Error (MSE) is basic measure of accuracy in which summation of all errors between observation (output) and forecast (predicted output) for all data, the errors are squared and then is divided by the total number of the data under study. The expression of MSE is defined as [8]

$M S E=\frac{1}{N} \sum_{i=1}^{N}\left(t_{i}-a_{i}\right)^{2}$

where $\mathrm{N}$ is the samples number, $\mathrm{t}$ is an output and a is predicted output.

The latter is regression analysis, R.R is a technique in examining the relationship between two variables (variable of interest and related predicted variable) and usually it is presented by drawing a straight line [9-10].

\section{RESULTS AND DISCUSSION}

Based on elemental analysis, all synthesized compounds were found to be in good agreement with the theoretical values. The molar conductance value of the complexes in chloroform was found at $0 \Omega^{-1} \mathrm{~cm}^{2} \mathrm{~mol}^{-1}$ reflecting the non-conductive nature of the solution at room temperature [11].

The strong bands of $(\mathrm{C}-\mathrm{N})$ of the ligands appeared at $1630 \mathrm{~cm}^{-1}$ which shifted to lower 
frequency, $1605-1618 \mathrm{~cm}^{-1}$ upon coordination to metal centers, indicating the involvement of the azomethine nitrogen in the complexation[12-13]. This can be explained by the donation of lone pair of electrons from the nitrogen to the empty $d$-orbitals of the transition metals, lowering the electron density of the $\mathrm{C}=\mathrm{N}$ and reducing the energy of the bond. The $(\mathrm{C}-\mathrm{O})$ bands in the region $1248-1220 \mathrm{~cm}^{-1}$ of the free ligands shifted to higher wavenumbers of $1221-1318 \mathrm{~cm}^{-1}$ in the complexes, indicating that the phenolic oxygen is also involved in complexation [12]. The appearance of new bands in complexes in the range of 596- 598 and 434-494 $\mathrm{cm}^{-1}$, which have been assigned to the $v(\mathrm{Pd}-\mathrm{N})$ and $v(\mathrm{Pd}-\mathrm{O})$, respectively [14-15]. Thus, it may be deduced that the ligands bind to the metal ion as bidentate fashion $(\mathrm{N}, \mathrm{O})$ in 2:1 ratio at azomethine nitrogen and the oxygen atoms [13].

${ }^{1} \mathrm{H}$ NMR of L1c for the phenolic proton $(\mathrm{C}-\mathrm{OH})$ appeared as a singlet at a far downfield region of $13.48 \mathrm{ppm}$ indicating deshielding by oxygen. This phenolic moiety was deprotonated upon complexation to form PdL1c. The presence of proton attached to the $\mathrm{C}=\mathrm{N}$ was detected as a singlet at $8.40 \mathrm{ppm}$ and it shifted upfield to $7.69 \mathrm{ppm}$ upon complexation, as similarly reported by [12]. These suggesting the coordination of azomethine nitrogen and oxygen to the palladium atom.

Table 1 tabulates the antibacterial activity of compounds against bacteria at $50 \mu \mathrm{m}$. From the table, it can be seen that the diameter of four complexes (NiL1d, PdL1d, NiL1c and PdL1c) are in the range of 6 to 10 in bacteria of E. coli, B. subtilisand S. aureus. It showed that the inhibition zone is weakly active since the range is less than $10 \mathrm{~mm}[16]$.

Table 1. Antibacterial activity of compounds against bacteria at $50 \mu \mathrm{M}$

\begin{tabular}{ccccc}
\hline \multirow{2}{*}{ Bacteria } & \multicolumn{4}{c}{ Complexes } \\
& NiL1d & PdL1d & NiL1c & PdL1c \\
\hline E. coli & 6 & 6 & 6 & 10 \\
B. subtilis & 6 & 7 & 7 & 6 \\
S. aureus & 8 & 7 & 7 & 6 \\
\hline
\end{tabular}

Fig. 4 shows the diameter of the complexes against bacteria. Three observations are observed. The first is, the diameter of NiL1d [17] PdL1d and NiL1c [18] are $6 \mathrm{~mm}$ and the diameter of PdL1c [19] is $10 \mathrm{~mm}$ in E. coli. The second is, the diameter of NiL1d and PdL1c is $6 \mathrm{~mm}$ and 
the diameter of PdL1d and NiL1c is $7 \mathrm{~mm}$ in B. subtilis. The third is, the diameter of NiL1d is $8 \mathrm{~mm}$ and the diameter of PdL1d and NiL1c is $7 \mathrm{~mm}$ and the diameter of PdL1c is $6 \mathrm{~mm}$ in $S$. aureus. Generally, all the diameters of these complexes are lower than $10 \mathrm{~mm}$ and it is considered as weakly active, thus supported the result.

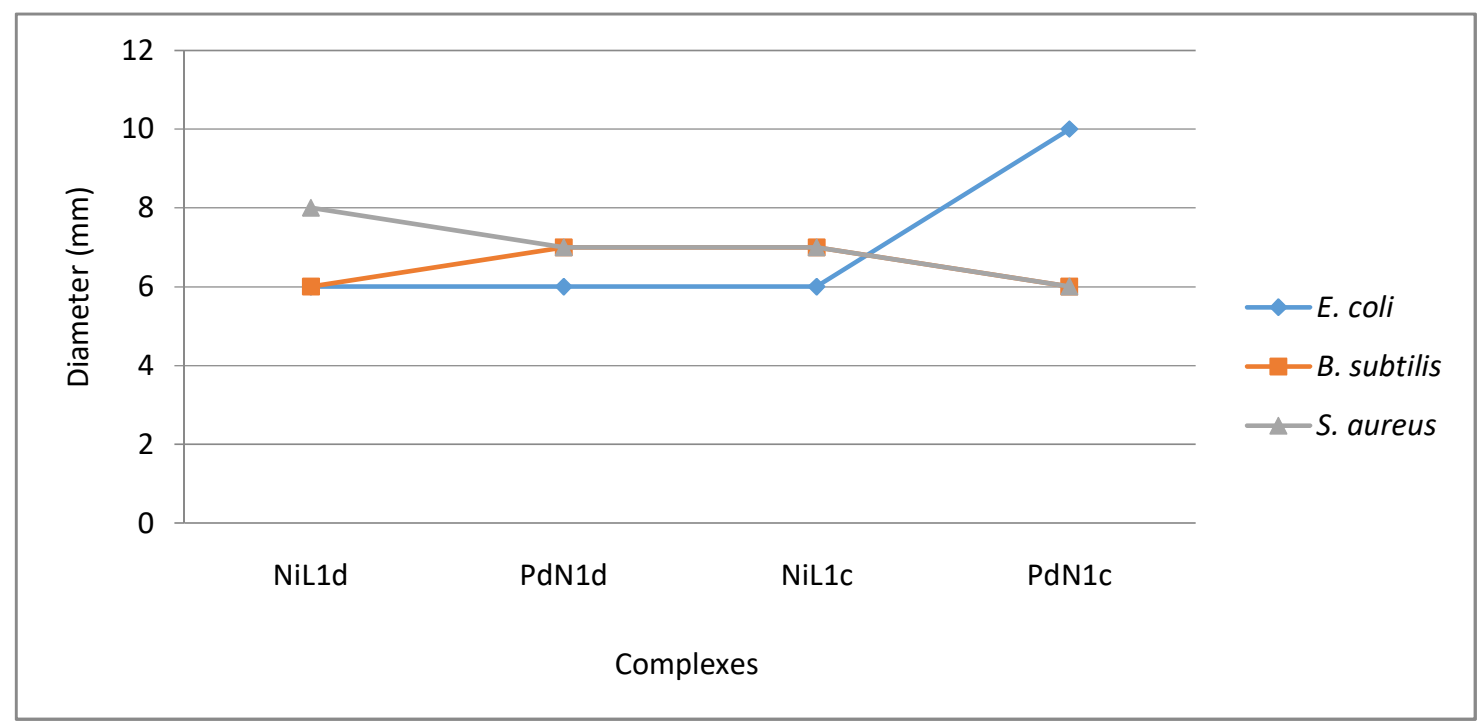

Fig.4. Inhibition against bacteria (Naming of the complexes for Pd are PdL1d, PdL1c)

Fig. 5shows multilayer feedforward neural network architecture and design used to train the network on this study. It consists of 4 inputs, 10 nodes in hidden layer and 1 output. There activation function are sigmoidal and purelin in updating the weight and biases during the network development.

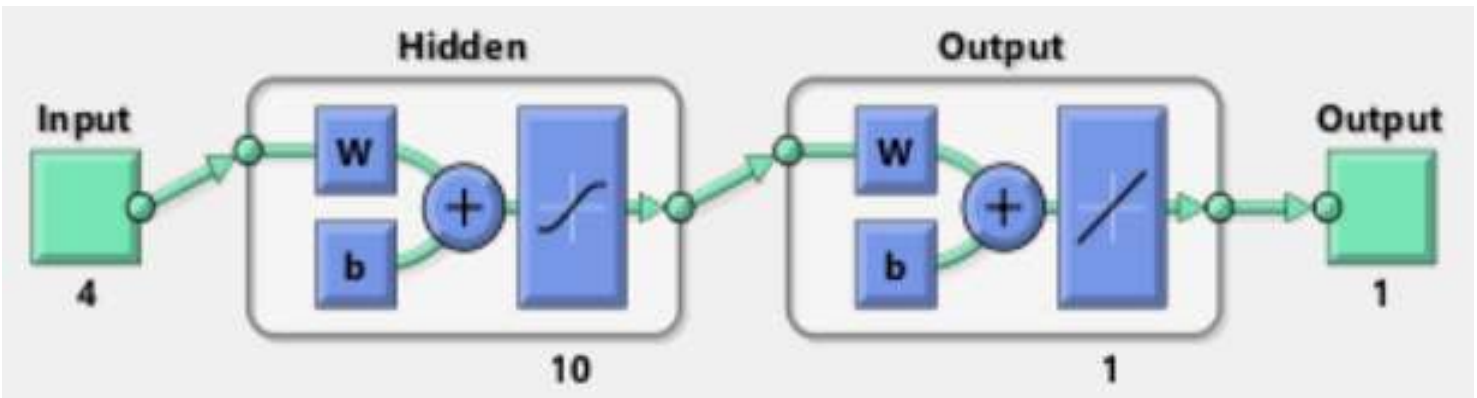

Fig.5. Multilayer feedforward neural network architecture and design

Fig. 6 shows MSE and best training performance of regression plot. During network training, the progress is constantly updated in the training stage. Of most interest are the performance, the magnitude of the gradient of performance and the number of validation checks. The magnitude of the gradient and the number of validation checks are used to terminate the training. In this figure, the training achieves its optimum level at epoch 5 with the 
performance of $1.948 \times 10^{-28}$.



Fig.6. MSE and best training performance

Fig. 7 shows regression plot for training data set. The dashed line represents the perfect result in which output is same as predicted output. The solid line represents the best fit linear regression line between output and predicted output. The $\mathrm{R}$ value is an indication of the relationship between output (target) and predicted output (output). The $\mathrm{R}$ value is 1 , this indicates a good fit. In other note, there is an exact linear relationship between output and predicted output. The relationship is presented by:

Output $=(R *$ Target $\left.)+1 \times 10^{-14}\right)$ and $\mathrm{R}=1$. 


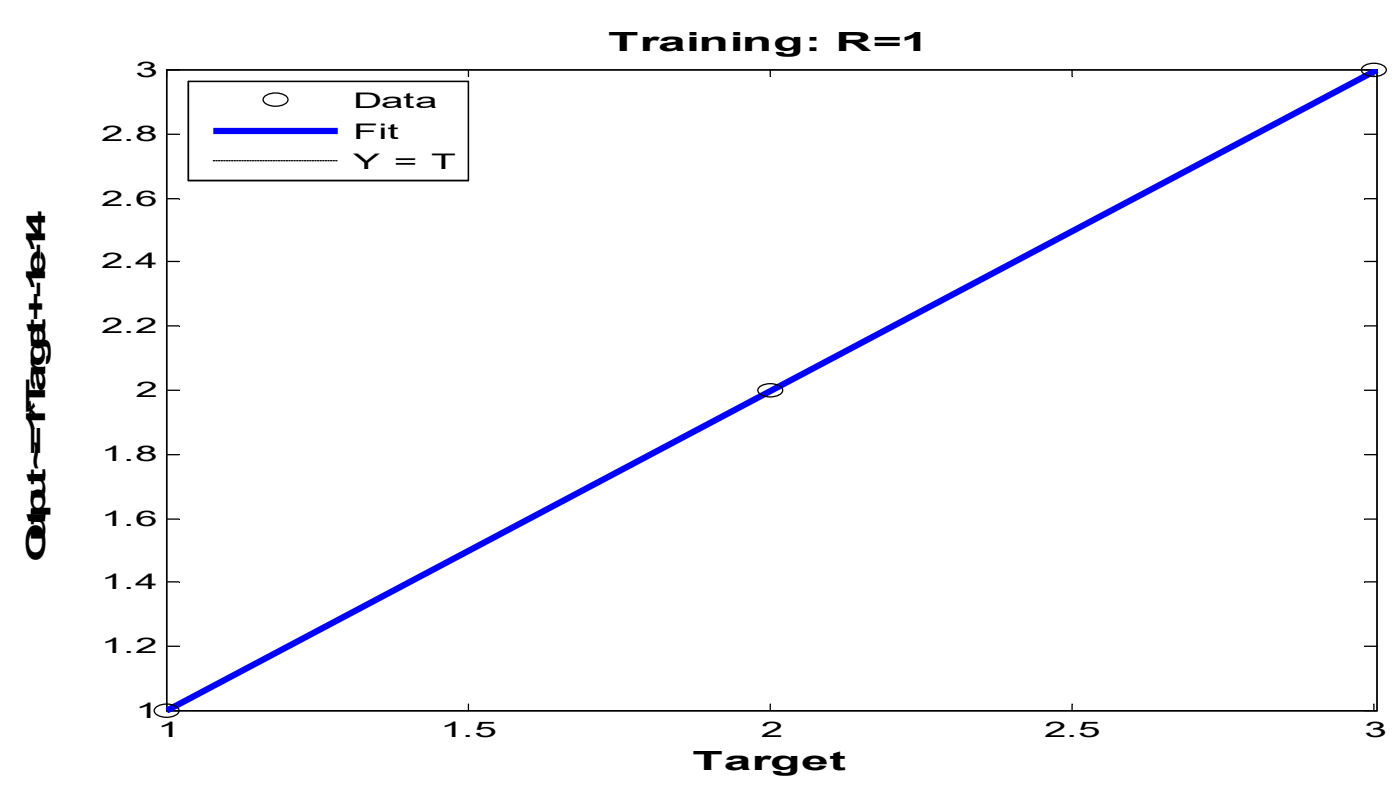

Fig.7. Regression plot for training data set.

\section{CONCLUSION}

The bidentate Schiff base ligands have been synthesized and their coordination behaviour with $\mathrm{Pd}(\mathrm{II})$ and $\mathrm{Ni}(\mathrm{II})$ metal ions have also been studied. All complexes were found to have square planar geometry where the ligands act as bidentate manner coordinated through azomethine nitrogen and oxygen atoms. The antibacterial screening of the compounds led to the conclusion that ligands metal complexes are inactive. Furthermore, the extending of the complexes against bacteria using multilayer feedforward neural network with Levenberg Marquardt training algorithm showed a good developed model with the regression, $\mathrm{R}$ is equal to 1 and low MSE value of $1.948 \times 10^{-28}$ at epochs 5 . The finding in this study is significant, thus contributed to the design of antibacterial agent especially to the bidentate Schiff base complexes.

\section{ACKNOWLEDGEMENTS}

The authors would like to thank UniversitiTeknologi MARA for grant no 600-RMI/DANA 5/3/REI (13/2015) and DrNazlina Ibrahim from UniversitiKebangsaan Malaysia for providing antibacterial facility. 


\section{REFERENCES}

[1] Karakaya C, Dede B, Cicek E. Novel metal (II) complexes with bidentate Schiff base ligand: Synthesis, spectroscopic properties and dye decolorization functions. Acta Physica Polonica A, 2016, 129(2):208-212

[2] Vigato PA, Tamburini S. The challenge of cyclic and acyclic Schiff bases and related derivatives. Coordination Chemistry Reviews, 2004, 248(17):1717-2128

[3] Mangamamba T, Ganorkar MC, Swarnabala G. Characterization of complexes synthesized using Schiff base ligands and their screening for toxicity two fungal and one bacterial species on rice pathogens. International Journal of Inorganic Chemistry, 2014, 2014:1-22

[4] Bouzerafa B, Ourari A, Aggoun D, Ruiz-Rosas R, Ouennoughi Y, Morallon E. Novel nickel (II) and manganese (III) complexes with bidentate Schiff-base ligand: Synthesis, spectral, thermogravimetry, electrochemical and electrocatalytical properties. Research on Chemical Intermediates, 2016, 42(5):4839-4858

[5] Kuz'min VE, Artemenko AG, Lozytska RN, Fedtchouk AS, Lozitsky VP, Muratov EN, Mescheriakov AK. Investigation of anticancer activity of macrocyclic Schiff bases by means of 4D-QSAR based on simplex representation of molecular structure. SAR and QSAR in Environmental Research, 2005, 16(3):219-230

[6] Taib MN, Andres R, Narayanaswamy R. Extending the response range of an optical fibre pH sensor using an artificial neural network. Analytica Chimica Acta, 1996, 330(1):31-40

[7] Hunt B. R., Lipsman R. L., Rosenberg J. M. A guide to MATLAB: For beginners and experienced users. England: Cambridge University Press, 2014

[8] Murphy AH. Skill scores based on the mean square error and their relationships to the correlation coefficient. Monthly Weather Review, 1988, 116(12):2417-2424

[9] Draper N. R., Smith H. Applied regression analysis. New Jersey: John Wiley and Sons, 2014

[10] Montgomery D.C., Peck E. A., Vining G. G. Introduction to linear regression analysis. New Jersey: John Wiley and Sons.2015

[11] Tyagi M, Chandra S, Tyagi P. Mn (II) and Cu (II) complexes of a bidentate Schiff's base ligand: Spectral, thermal, molecular modelling and mycological studies. SpectrochimicaActa Part A: Molecular and Biomolecular Spectroscopy, 2014, 117:1-8 
[12] Şenol C, Hayvali Z, Dal H, Hökelek T. Syntheses, characterizations and structures of NO donor Schiff base ligands and nickel (II) and copper (II) complexes. Journal of Molecular Structure, 2011, 997(1):53-59

[13] Nair MS, Arish D, Joseyphus RS. Synthesis, characterization, antifungal, antibacterial and DNA cleavage studies of some heterocyclic Schiff base metal complexes. Journal of Saudi Chemical Society, 2012, 16(1):83-88

[14] Shebl M. Synthesis, spectral studies, and antimicrobial activity of binary and ternary $\mathrm{Cu}$ (II), Ni (II), and Fe (III) complexes of new hexadentate Schiff bases derived from 4, 6-diacetylresorcinol and amino acids. Journal of Coordination Chemistry, 2009, 62(19):3217-3231

[15] Ouf AE, Ali MS, Saad EM, Mostafa SI. pH-metric and spectroscopic properties of new 4-hydroxysalicylidene-2-aminopyrimidine Schiff-base transition metal complexes. Journal of Molecular Structure, 2010, 973(1):69-75

[16] Manan MA, Tahir MI, Crouse KA, How FN, Watkin DJ. Synthesis, characterization and antibacterial activity of Schiff base derived from s-methyldithiocarbazate and methylisatin. Journal of Chemical Crystallography, 2012, 42(2):173-179

[17] Tajuddin AM, Ramasamy K, Yamin BM, Alharthi AI, Bahron H. DFT analysis and bioactivity of 2-((E)-(4-methoxybenzylimino) methyl) phenol and its $\mathrm{Ni}$ (II) and Pd (II) complexes. Arabian Journal of Chemistry, 2016, 10(6):769-780

[18] Bahron H, Tajuddin AM, Ibrahim WN, Fun HK, Chantrapromma S. Crystal structure of bis $\{2-[(\mathrm{E})-(4-m e t h o x y l b e n z y l)$ iminomethyl $]$ phenolato- $\kappa 2 \mathrm{~N}, \quad \mathrm{O} 1\}$ nickel (II). ActaCrystallographica Section E: Structure Reports Online, 2014, 70(8):104-106 [19] Tajuddin AM, Bahron H, Hanafiah RM, Ibrahim N, Fun HK, Chantrapromma S. Crystal structure of bis $\{2-[(\mathrm{E})-(4-$ fluorobenzyl) iminomethyl] phenolato- $\kappa 2 \mathrm{~N}, \mathrm{O}\}$ nickel (II). ActaCrystallographica Section E: Structure Reports Online, 2014, 70(10):252-255

\section{How to cite this article:}

Tajuddin A M, Ismail N, Kassim K, Bahron H. Synthesized and extending the bidentate schiff base complexes using multilayer feedforward neural network. J. Fundam. Appl. Sci., 2017, 9(4S), 952-963. 